\title{
Channel hoppers land chemistry Nobel
}

Jim Giles

Two structural biologists credited with transforming our understanding of how cells work have been awarded the 2003 Nobel Prize in Chemistry.

Peter Agre of Johns Hopkins University in Baltimore and Roderick MacKinnon of the Rockefeller University in New York share the prize for experiments that revealed the intricate workings of the channels that allow ions and water to enter and leave cells.

MacKinnon is perhaps the most widely tipped Nobel winner of recent years. In a landmark 1998 paper (D. A. Doyle et al. Science 280, 69-77; 1998), he and his colleagues provided the first detailed three-dimensional picture of a protein that acts as a channel to control the flow of potassium ions across cell membranes. This channel is immensely important to neuroscientists, as the flow of potassium ions helps to generate the voltage pulses that brain cells use to communicate.

Before MacKinnon's paper, many biologists had questioned whether the technique he used - X-ray crystallography - could be used to image membrane proteins. The method involves forming crystals of the protein to be studied, but researchers had previously failed to get large enough quantities of channel proteins for effective crystallization. MacKinnon experimented with potassiumchannel proteins from many different organisms, eventually extracting enough from the bacterium Streptomyces lividans.

When he went on to describe how such channels open, close and prevent other ions from entering, many colleagues felt that he
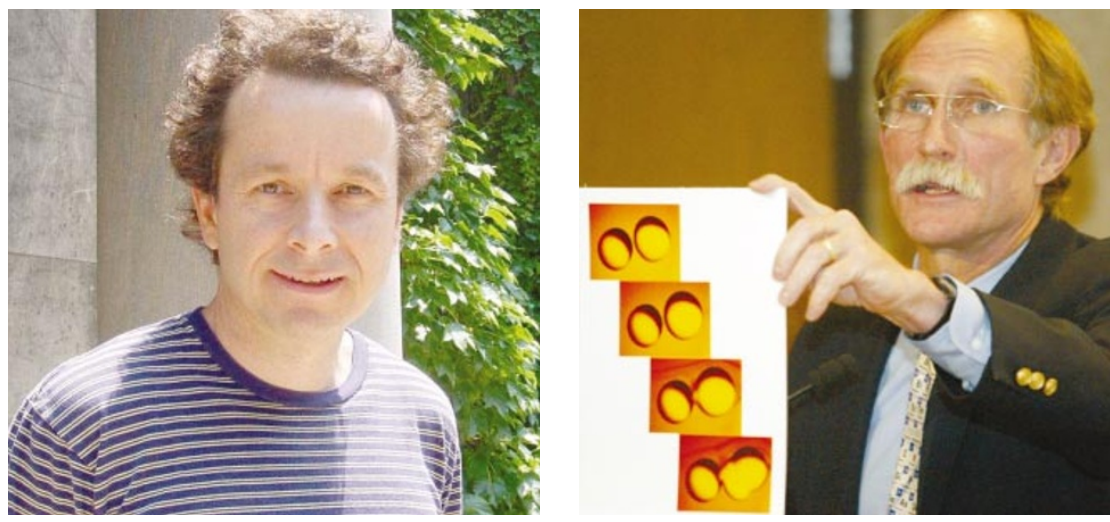

Roderick MacKinnon (left) and Peter Agre's work on cell-membrane proteins has won them recognition.

deserved a Nobel. "His work is a tour de force," says John Walker, a structural biologist at the University of Cambridge, UK. "The award is absolutely spot on and richly deserved."

MacKinnon was on holiday when the prize was announced, and couldn't be informed directly by the Nobel prize committee. "My assistant called to tell me but I didn't believe him," says MacKinnon. "I had to do a Google search on 'Nobel prize." When asked what he would do with the prize money, MacKinnon suggested that buying a mobile phone might be a good idea.

Agre's breakthrough came in 1988, when he cracked a problem that had survived more than a century of study - the way in which cells absorb and flush out water. Agre and his colleagues, while studying cell membranes, identified a previously unknown protein in red blood cells (B. M. Denker, B. L. Smith, F. P.
Kuhajda and P. Agre J. Biol. Chem. 263, 15634-15642; 1988). "No one had seen it before, but we found that it was the fifth most abundant protein in the cell," says Agre. "That's like coming across a big town that's not on the map. It gets your attention."

The protein, now known as aquaporin 1, is a cell-membrane channel that lets water pass through, but not other substances. "We weren't looking for the water channel," says Agre."We were very lucky."

"Agre's work changed the way we think about membranes," says Stefan Hohmann, a cell biologist at Gothenburg University in Sweden. The studies could have many medical spin-offs, he adds. Aquaporins play an important role in the brain swelling that can occur after stroke, for example, and blocking their function could help to reduce this effect.

www.nobel.se

\section{Economics prize for duo who resolved random results}

\section{Philip Ball}

The Nobel prize for economics has been awarded to researchers whose mastery of mathematical methods could have consequences way beyond the 'dismal science'.

The prize was awarded to Robert Engle of New York University and Clive Granger of the University of California, San Diego, for their development of methods to analyse apparently random fluctuations in economic data.

The dynamics of economic statistics including indices of national output, stock prices and exchange rates - pose a daunting challenge to scientific study. These indices tend to vary unpredictably over time, with periods of high volatility interspersed with calmer spells.

Engle, an American who trained as a physicist at Cornell University, devised statistical models to describe the plots of

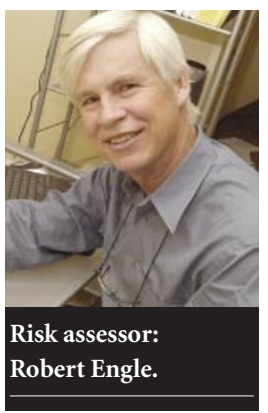

such indices over time - known as time series - using a concept that he called autoregressive conditional heteroskedasticity (ARCH). Models of market volatility based on the idea are now widely used by market analysts

and bankers to evaluate risk.

Welsh-born Granger, meanwhile, developed statistical methods that help analysts to deal with time series that fluctuate around a moving baseline, by combining them in a way that removes their long-term drift, through a phenomenon that he called co-integration. This makes such data amenable to conventional statistical

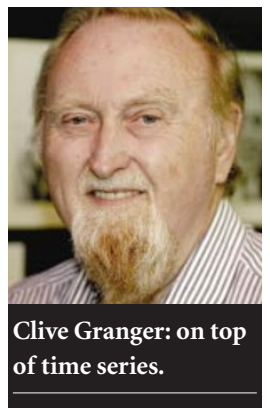

analysis, and helps to identify causal connections between data sets.

"If you are going to give a prize for economic timeseries analysis, these are the two to give it to," says economist Paul Ormerod of London-based company Volterra Consulting.

Besides economics, the winners' methods have found widespread application in the analysis of nonlinear systems in such diverse areas as climatology, physiology and physics. Granger's techniques have proved to be particularly versatile and have been used, for example, to assess human influences on climate change. 